\title{
PROBLEM FILSAFAT PENDIDIKAN ISLAM: PROYEKSI, ORIENTASI KE ARAH FILSAFAT PENDIDIKAN ISLAM PARIPURNA
}

\section{Muhammad Hatim*}

\begin{abstract}
Abstrak: Kajian filsafat pendidikan Islam di Indonesia masih terbatas dan hanya ada di kalangan perguruan tinggi. Padahal secara esensi filsafat pendidikan Islam sebagai pondasi dasar untuk mengetahui gerak laju pertumbuhan dan perkembangan pendidikan Islam. Selama ini filsafat pendidikan Islam hanya berkutat pada kajian-kajian tokoh, konsep, teori dan sejarahnya saja, tanpa menyentuh nilai dasar dari pendidikan Islam itu sendiri. Terdapat banyak problem pada kajian filsafat pendidikan Islam saat ini, diantaranya adalah tentang tujuan dari pendidikan Islam, kurikulum pendidikan Islam, dualitas pendidikan Islam yang masih saja diperdebatkan, serta proyeksi pendidikan Islam antara tradisi dan adaptasi. Penelitian ini bertujuan untuk mengungkap permasalahan yang ada di dalam filsafat pendidikan Islam.
\end{abstract}

Kata Kunci: Problem, Filsafat, Pendidikan Islam

\section{Pendahuluan}

$\mathrm{P}$

endidikan Islam mempunyai spesifikasi tersendiri dibandingkan dengan pendidikan umum. Pendidikan Islam berpijak pada ajaran-ajaran Islam yang termaktub dalam sumber oriented diantaranya, (Al-Qur'an dan Hadis), pemikiran keislaman, konsep-konsep keislaman, dan jalan hidup Islam. Melalui pendidikan Islam umat Islam sanggup meraih kejayaan pada awal abad $2 \mathrm{H}$ sampai $5 \mathrm{H}$. Pendidikan Islam pada waktu itu sudah melahirkan para pemikir-pemikir yang patut dibanggakan umat Islam, seperti Al-Kindi, Al-Razi, Al-Farabi, Ibn Sina, AlGhazali, Ibn Tufail, Ibn Rusyd, dan sebagainya. Mereka tidak hanya

\footnotetext{
* Peneliti Rumpun Bambu Riset (RBR) Nusa Tenggara Barat
} 
berjasa dalam membangun peradaban Umat Islam. Lebih dari itu, mereka mampu menginspirasi era kejayaan dunia Barat.

Kegemilangan umat Islam memang tidak terlepas dari pola pengajaran pendidikan Islam. Jiwa pendidikan yang dilandasi oleh semangat agama Islam, sudah menanamkan namanya dalam ranah sosial. Sir Muhammad Iqbal pernah mengatakan bahwa pendidikan Islam berperan dalam membentuk Insan Kamil. Manusia yang digariskan oleh Iqbal mengindikasikan bahwa kesempurnaan manusia dapat dicapai melalui pendidikan Islam. Lain halnya dengan Fazlurrahman yang mengkonsepsikan pendidikan Islam sebagai pembentuk generasi-generasi yang berpandangan maju. Senada dengan Rahman, Syed Naquib Al-Attas merumuskan pendidikan Islam sebagai pembentuk kepribadian manusia yang sesuai dengan ajaran Islam serta mampu memformulasikannya dalam realitas sosial.

Pendapat yang dikemukakan oleh pemikir Islam, tidak sepenuhnya dipahami oleh para praktisi pendidikan Islam, dalam hal ini misalnya lembaga, kementrian, serta institusi kependidikan. Titik persoalan tersebut dapat dilihat dalam era globalisasi dan modernisasi seperti sekarang ini. Dimana pendidikan Islam hanya mampu bertahan apabila mengadopsi gaya pendidikan model Barat, baik dalam segi materi, tujuan, strategi, maupun metodologinya. Jika ditelisik dalam kacamata filsafat pendidikan Islam, maka problem-problem tersebut merupakan esensialitas epistemic pendidikan Islam.

Problem pendidikan Islam tersebut dapat dikatakan sebagai ironis bagi Islam sendiri. Sebab tidak dapat dipungkiri bahwa konsep-konsep Islam yang sudah dirumuskan jauh sebelum berkembangnya pendidikan Islam, sampai hari ini belum tampak strukturasi keilmuannya. Dalam hal ini Ismail Raji al-Faruqi menganggap bahwa selama ini visi pendidikan Islam kabur dalam angan-angan ke-Barat-an. Pendapat tersebut memang benar adanya, konsep-konsep yang selama ini ada dalam pendidikan Islam lebih banyak menggunakan sumber-sumber dari Barat, misalnya dalam hal filsafat pendidikan Islam, kajian tentang aliran-aliran filsafat 
pendidikan Islam menggunakan tipologi yang dikenalkan oleh Theodore Brameld, tidak menggunakan tipologi filosofis yang pernah diformulasikan para pemikir-pemikir Islam. Mengutip pendapat Abdul Munir Mulkhan, hal itu ditengarai sebagai problem struktural-fungsional keilmuan.

Problem mendasar tersebut berakibat terhadap proses pendidikan Islam itu sendiri. $V$ is a vis dalam menggunakan sumber Islam atau Barat. Berakibat pada jalan pengetahuan yang cenderung untuk menutup kemungkinan pengembangan pengetahuanpengetahuan mutakhir. Nalar epistemik yang digunakan lembaga pendidikan Islam tidak dapat berpengaruh terhadap mutu lulusan dalam bersaing dengan lembaga pendidikan umum. Kecenderungan mutakhir dari lembaga pendidikan Islam hanya menjadikan output pendidikannya shaleh secara individual, dan tidak shaleh secara sosial. Hal ini tidak terlepas dari pola pengajaran yang hanya mengandalkan normatifitas sumber-sumber Islam, daripada menjelajah kepada rekonstruksi sumber-sumber tersebut.

Dengan demikian pendidikan Islam tidak dapat berbicara lebih di dalam era elektronika sekarang ini. Lulusan yang diharapkan mampu memberi wadah bagi terciptanya produk-produk Islam, malahan hanya mampu memberikan doktrin-doktrin keislaman yang radikal.

\section{Visi Pendidikan Islam}

Secara sederhana, visi dapat diartikan sebagai, keinginan, citacita, harapan dan impian tentang masa depan. Keberhasilan dan reputasi kelembagaan sangat tergantung pada sejauh mana visi yang diembannya dapat dipenuhi. Oleh karenanya, sebuah lembaga memerlukan visi yang jelas dan dapat memberikan motivasi dan kekuatan gerak untuk mencapai prestasi menuju masa depan dengan berbagai keunggulannya. Dalam sistem pendidikan Islam, keberadaan visi dan misi menempati posisi penting. Visi harus dirumuskan lebih awal yang kemudian dituangkan dalam misi, yaitu program-program dan kegiatan-kegiatan untuk mewujudkan visi tersebut, dan lebih jauhnya adalah menyusun program aksi di dalam 
sebuah rencana yang matang dan fleksibel untuk dapat dilaksanakan dalam jangka waktu tertentu secara bertahap.

Visi dan misi pendidikan Islam yang merupakan harapan, citacita, dan tujuan pendidikan Islam, pada dasarnya dibangun dari nilai-nilai Islam dan hasil analisa terhadap keberadaan pendidikan Islam. A. Syafei Ma'arif merumuskan visi pendidikan Islam, yaitu "manusia yang unggul secara intelektual, kaya dalam amal, serta anggun dalam moral dan kebijakan" (Usa, 1991: 155). Dalam konteks pendidikan Nasional, Tilaar merumuskan visi pendidikan Islam, yakni mewujudkan manusia Indonesia yang takwa dan produktif sebagai anggota masyarakat Indonesia yang ber-Bhineka (Tilaar, 2000: 149). Manusia Indonesia yang dicita-citakan adalah manusia yang shaleh dan produktif. Abad ke-21 menuntut kedua kualitas manusia semacam ini. Seperti yang di kemukakan mengenai trend abad 21, agama dan intelek akan saling bertemu. Manusia Indonesia yang dicita-citakan adalah manusia yang takwa dan beriman sekaligus produktif dengan mengusai ilmu pengetahuan dan teknologi bagi peningkatan taraf hidupnya.

Visi yang diemban oleh pendidikan Islam sejalan dengan proses cita-cita setiap manusia yang ada di dalam dunia. Sebagaimana yang terdapat dalam Q.S. Adzariyat ayat 56 Yaitu sebagai hamba Tuhan yang senantiasa dapat mendapatkan kesejahteraan jasadi maupun rohani. Namun yang menjadi pertanyaan apakah visi pendidikan Islam tersebut sudah sejalan dengan perubahan yang ada di kehidupan dunia? Sedangkan dunia kita tahu sudah menuju kepada global village, global science, dan global civilization. Kenyataan yang terjadi di dalam pendidikan Islam sering dijumpai adanya kerancuan dalam penggunaan istilah "pendidikan Islam". Bila kita menyebut pendidikan Islam konotasinya sering dibatasi pada "pendidikan agama Islam". Padahal bila dikaitkan degan kurikulum pada lembaga pendidikan formal atau non-formal, pendidikan agama Islam hanya terbatas pada bidang-bidang studi agama seperti, Tauhid, Fiqh, Tarikh Nabi, membaca al-Qur'an, Tafsir, dan Hadis.

Selain permasalahan peristilahan tersebut pendidikan Islam masih merupakan turunan dari pendidikan umum, dalam artian 
bahwa pendidikan Islam yang mempunyai daya tawar yang tidak hanya berpusat pada teosentris maupun antroposentris. Sampai saat ini masih berpusat pada salah satunya. Kecenderungan mutakhir dalam pendidikan Islam hanya mengedepankan kecukupan mendidik dan mencerdaskan diri sendiri dengan penggunaan tekhnologi informasi khusunya dengan fasilitas computer. Sehingga trend pembelajaran dewasa ini dan mungkin ke depannya hanya bertumpu pada pencerdasan individual. Praktek pendidikan yang tidak sesuai dengan visi pendidikan tidak berfungsi sebagai proses transformasi pada diri peserta didik dan masyarakat. Bahkan, praktek pendidikan seringkali menjadi biang terjadinya problem sosial .Hal ini antara lain dapat dilihat dari adanya kenyataan bahwa proses pendidikan yang ada cenderung berjalan monoton, indoktrinatif, teacher-centered, top-down, sentralistis, mekanis, verbalis, kognitif, dan misi pendidikan telah misleading. Tidak heran jika ada kesan bahwa praktek dan proses pendidikan Islam steril dari konteks realitas, sehingga tidak mampu memberikan kontribusi yang jelas terhadap berbagai problem yang muncul. Praktek pendidikan Islam yang dianggap misleading ini merupakan bukti bahwa belum ada pemahaman yang memadai tentang konsep dan implementasi pendidikan Islam dalam era kontemporer. Pendidikan Islam banyak mengalami reduksi, baik dari aspek visi-misi, makna maupun prakteknya.

Tidak berdayanya (powerlessness) pendidikan Islam tersebut menjadi keprihatinan bersama, mulai dari pakar dan praktisi pendidikan di lembaga pendidikan formal, tokoh masyarakat hingga orang tua di rumah. Pendidikan (khususnya agama) dianggap tidak cukup efektif memberikan kontribusi dalam penyelesaian masalah. Bahkan, ia menjadi part of the problem. Karena itu, banyak gagasan muncul tentang perlunya melakukan reinterpretasi dan reorientasi, termasuk melakukan perubahan paradigma dari praktek pendidikan yang selama ini berjalan. Perubahan paradigma tersebut antara lain berkaitan tentang pendidikan yang harus diselenggarakan dengan pendekatan akademis, bukan birokratis, pendidikan harus berorientasi mencetak peserta didik bermental mencari ilmu, bukan 
menunggu ilmu, peserta didik harus dididik mencadi orang aktif, bukan pasif, pendidikan harus berorientasi pada peserta didik (student oriented), bukan pendidik atau negara (teacher and state Oriented), manusia harus dilihat secara antroposentris yang teosentrik, bukan hanya antroposentris, pengelolaan pendidikan tidak boleh sentralistis, tapi harus desentralistis, pendidikan agama tidak boleh disampaikan secara dogmatis saja, dan pendidikan harus bersifat inklusif, integralistik dan holistik.

\section{Epistemologi Pendidikan Islam}

Pengertian epistemologi menurut P. Hardono Hadi menyatakan bahwa cabang filsafat yang mempelajari dan mencoba menemukan kodrat dan skope pengetahuan, pengandaianpengandaian dan dasarnya, serta pertanggungjawaban atas pernyataan mengenai pengetahuan yang dimiliki (Gallagher, 1994: 8-9). Dagobert D. Runes. Dia menyatakan, bahwa epistemologi adalah cabang filsafat yang membahas sumber, struktur, metodemetode dan validitas pengetahuan. Sementara itu, Azyumardi Azra menambahkan, bahwa epistemologi sebagai "ilmu yang membahas tentang keaslian, pengertian, struktur, metode dan validitas ilmu pengetahuan" (Qomar, 2005: 4). Dengan demikian Epistemologis merupakan cabang dari filsafat ilmu. Filsafat yang mengkhususkan bergerak dalam ranah cara pengcarian kebenaran. Filsafat dan epistemologis menjadi sebuah keterpaduan yang tidak dapat dipisahkan, sehingga epistemologis dianggap perlu untuk dillakukan pengkajiaannya.

Dalam sejarah keilmuan, terdapat dua macam gelombang epistemologi yang besar, antara Barat dan Timur. Kiranya, dalam epistemologi Barat dapat ditemukan dalam dua epistemologi besar yaitu antara rasionalisme dan empirisme. Meskipun masih ada epistemologi yang lainnya, namun kedua epistemologi sampai sekarang masih kuat peranannya dalam keilmuan mutakhir. Epistemologi Barat tersebut sangat mengistimewakan peranan manusia dalam memecahkan "segala sesuatu", dan dalam waktu yang bersamaan menentang dimensi spiritual yang kemudian 
menjadi sumber utama krisis epistemologis yang berimplikasi pada krisis pengetahuan, maka ada upaya untuk mencari pemecahan dengan mempertimbangkan epistemolog lain. Epistemologi seolaholah tidak mempunyai landasan transendalisme. Itulah salah satu kritik dari para pemikir-pemikir kontemporer. Bahkan Nietzsche menyebut sebagai sebuah "kegagalan" Barat dalam mengkonsepsikan wilayah keilmuan (Wibowo, 2002: 20).

Sedangkan untuk epistemologi Islam ingin memberikan apa yang tidak ada di dalam epistemologi Barat. Menurut Ziauddin Sardar epistemologis Islam menekankan totalitas pengalaman dan kenyataan serta menganjurkan banyak cara untuk mempelajari alam, sehingga ilmu bisa diperoleh dari wahyu maupun akal, dari obeservasi maupun intuisi, dari tradisi maupun spekulatif teoritis (Sardar, 1998: 54). Kemudian untuk model epistemenya sebagaimana terlihat dari pemikiran 'Abid al-Jabiri, ia mengkonsepsikan epistemologi sebagai basis keilmuan dalam mengambil pengetahuan dengan cara-cara Islam. 'Abid kemudian membagi epistemologi Islam menjadi Bayani, Burhani, dan Irfani, yang mempunyai ciri khas dalam memperoleh validitasnya.

Dengan mendasarkan kepada Islam untuk dijadikan sebagai basis epistemologinya, pendidikan Islam dituntut untuk secara subtil mengambil ilmu-ilmu yang lahir melalui proses keislaman. Namun yang menjadi hambatan selama ini pendidikan Islam hanya menerapkan pola yang tidak menyeluruh. Epistemologi pendidikan Islam masih dalam tekanan epistemologi pendidikan Barat. Pendidikan Islam belum dirumuskan secara jelas baik tujuan, metode, serta konsep-konsep yang mendasarinya. Para founding father pendidikan Islam malahan mengikuti rumusan-rumusan yang telah dilakukan oleh pemikir pendidikan Barat.

Corak pendidikan Barat mempunyai karakteristik yang merefleksikan pemikiran dan kebudayaan abad XVIII - XIX yang ditandai dengan isolasi terhadap agama, sekularisme Negara, materialism, penyangkalan terhadap wahyu, dan penghapusan nilainilai etika, yang kemudian digantikan denga pragmatisme (Usa, 1991: 155). Karakter pendidikan Barat tersebut masuk di dalam 
hamper semua sistem pendidikan Islam saat ini. Alasan logis dari peniruan terhadap model pendidikan Barat oleh umat Muslim dikarenakan untuk mencapai kemajuan, seperti yang terjadi di Barat, namun kenyataannya sangatlah jauh dari yang terjadi di Barat. Senada dengan yang dijelaskan oleh Ismail Raji' al-Faruqi yang mengatakan bahwa materi dan metodologi yang kini diajarkan di dunia Islam adalah jiplakan dari materi dan metodologi Barat (alFaruqi, 2003: 17).

Hal itu mengingatkan akan pembaharuan pendidikan yang terjadi pada abad ke-20 yang dilakukan oleh Mustafa Kemal Attaturk di Turki. Melalui semangat westernisasi, sekulerisme, dan nasionalisme, dia mengadakan perombakan pendidikan Islam secara mendasar dengan menutup Madrasah diganti dengan sekolah, menghapuskan pendidikan agama di sekolah-sekolah, menghapuskan bahasa Arab dan Persia dalam kurikulum sekolah, dan menukar tulisan Arab dengan tulisan Latin (Nasution, 1975: 149-152). Akan tetapi kenyataannya hingga sekarang Turki tidak mampu mencapai kemajuan peradaban sebagai yang dicapai Negara-negara Barat.

Untuk itu, persoalan-persoalan tersebut harus diselesaikan dengan jalan, meleburkan kedua epistemologi. Barat dan Timur merupakan kesinambungan dalam peradaban. Ada beberapa syarat untuk memecahkan problem tersebut, pertama, Merubah paradigma ideologis menjadi paradigma ilmiah yang berpijak pada wahyu Allah SWT. Sebab, paradigma ideologis ini -karena otoritasnya-dapat mengikat kebebasan tradisi ilmiah, kreatif, terbuka, dan dinamis. Praktis paradigma ideologis tidak memberikan ruang gerak pada penalaran atau pemikiran bebas bertanggung jawab secara argumentatif. Padahal, wahyu sangat memberikan keleluasaan bagi akal manusia untuk mengkaji, meneliti, melakukan observasi, menemukan, ilmu pengetahuan (ayat kauniyah) (Zaini, 1986: 4).

Dengan petunjuk wahyu Allah SWT. Dan paradigma ilmiah saja tanpa berpijak pada wahyu, tetap akan menjadi sekuler. Karena itu, agar epistemologi pendidikan Islam terwujud, maka konsekuensinya harus berpijak pada wahyu Allah. Kedua, Terkait 
dengan pengembangan kurikulum pendidikan Islam, hal-hal yang sifatnya masih melangit, dogmatis, dan transendental perlu diturunkan dan dikaitkan dengan dunia empiris di lapangan. Ilmuilmu yang berbasis pada realitas pengalaman empiris, seperti sosiologi, spikologi, filsafat kritis yang sifatnya membumi perlu dijadikan dasar pembelajaran, sehingga ilmu betul-betul menyentuh persoalan-persoalan dan pengalaman empiris (Zuhairini, 1995: 152).

\section{Dualisme Keilmuan}

Perkataan "dualisme" adalah gabungan dua perkataan yang berasal dari bahasa Latin yaitu "dualis" atau "duo" dan "ismus" atau "isme". "Duo" memberi arti kata dua sedangkan "ismus" berfungsi membentuk kata nama bagi satu kata kerja. Dualisme adalah dua prinsip yang saling bertentangan. Secara terminologi, dualisme dapat diartikan sebagai dua prinsip atau paham yang berbeda dan saling bertentangan (Bakar dan Surohim, 2005: 91-91). Oleh karena itu, dualisme ialah keadaan yang menjadi dua dan ia adalah satu sistem atau teori yang berdasarkan pada dua prinsip yang menyatakan bahwa ada dua substansi.

Dalam konteks pendidikan, Marwan Sarijo (Saridjo, 1996: 22) menyatakan bahwa istilah dualisme dan dikotomi memiliki makna yang sama yaitu pemisahan antara pendidikan umum dari pendidikan agama. Dengan pemaknaan di atas, dualisme dan dikotomi pendidikan adalah pemisahan sistem pendidikan antara pendidikan Islam dan pendidikan umum yang memisahkan kesadaran keagamaan dan ilmu pengetahuan atau ilmu umum. Dualisme dan dikotomi ini, bukan hanya pada tataran pemilahan tetapi masuk pada wilayah pemisahan. Dalam operasionalnya, pemisahan mata pelajaran umum dengan mata pelajaran agama, sekolah umum dan madrasah yang pengelolaannya memiliki kebijakan masing-masing.

Istilah dualisme bisa masuk dalam berbagai sistem, sebagaimana yang terdalam dalam keilmuan pemikiran Islam. Dualisme keilmuan dalam Islam ditengarai muncul dalam 
pernyataan Imam al-Ghazali mengenai dua ilmu, yaitu illmu wajib 'ain dan ilmu wajib kifayah. Perkataan tersebut seolah-olah telah menjungkirbalikkan kemapanan keilmuan yang sudah terbangun sejak abad II H/7 M di dalam imperium Islam. Istilah wajib 'ain dan wajib kifayah membagi keilmuan berdasarkan aspek kegunaannya semata. Khusus yang menjadi konsen wajib 'ain hanya berhubungan dengan wilayah-wilayah ilmu pengetahuan yang dapat mendorong menjadi manusia ahli beribadah secara literalis. Dalam hal ini disebutkan beberapa keilmuan seperti al-Qur'an, Hadis, Fiqh, akhlak, dan sebagainya. sedangkan untuk ilmu yang termasuk ke dalam wajib kifayahh antara lain ilmu-ilmu yang berhubungan dengan keahlian dokter, kimiawan, farmasi, astrologi, dan sebagainya. kiranya dalam hal ini ilmu-ilmu wajib kifayah mencakup segala ilmu yang tidak ada kaitannya dengan kesalehan individu sebagai hamba Allah Swt.

Di samping itu, kejadian lainnya yang bisa dianggap besar pengaruhnya terhadap dikotomi ilmu adalah fatwa yang sangat keras dan destruktif dari Ibn Shalih tentang hukum mempelajari Filsafat, yang kemudian menjadi pegangan penting bagi golongan Ahl al-Sunnah (Zaini, 1989: 9). Sebelumnya, memang sudah ada beberapa tokoh sudah menghujat dan menentang ilmu filsafat seperti Ibn Hazm, al-Ghazali, Ibn Taimiyah, dan Ibn al-Qoyyim, tetapi. Adanya fatwa-fatwa yang menentang habis ilmu-ilmu filsafat dan non agama menjadikan pendidikan Islam kehilangan dimensi dialektikal konkrit kemanusiaan dan memunculkan dimensi vertikal keabadian. Seharusnya antara dua dimensi tersebut menjadi karakteristik pendidikan Islam. Artinya, secara filosofis pendidikan Islam tidak menyentuh persoalan hidup yang multidimensional di dunia, tetapi juga menyangkut dimensi transendental. Karena itu, pendidikan Islam juga harus mampu menghasilkan output yang free agents capable of awakening to the conditioning of our society.

Setelah pernyataan-pernyataan diatas, ada sebuah pergeseran besar dalam keilmuan yang dikembangkan dalam dunia Islam. Ilmu-ilmu kegamaan dikembangkan sangat pesat dalam berbagai aspek kehidupan umat Muslim. Awal kebangkitan Islam yang 
bermuara di dalam keterpaduan ilmu-ilmu umum dan agama Islam segera digantikan hanya monokotomik ilmu. Pendidikan Islam yang tugasnya untuk mengajarkan berbagai macam keilmuan, kemudian hanya digunakan elit politik untuk mengajarkan ilmu-ilmu agama semata. Dalam pengamatan Syed Hossein Nasr fenomena itu diakibatkan oleh kemunduran yang diakibatkan perombakan besarbesaran dalam tingkah laku Muslim. Artinya hasrat umat Muslim bukan berlandaskan ilmu pengetahuan, melainkan perubahan perilaku lebih diperlukan adanya.

Dalam analisis Fazlurrahman dinyatakan bahwa semenjak masa klasik (850 - 1200 M) sampai masa awal abad pertengahan (1200 $1800 \mathrm{M}$ ), umat Islam memiliki kekayaan ilmu dan pengetahuan. Akan tetapi memasuki pertengahan sampai akhir abad ke 19 M umat Islam mengalami kemunduran dalam bidang Pendidikan (Fazlurrahman, 1997: 103). Di tengah keterpurukan pada sistem pendidikan Islam yang terjadi adalah adopsi besar-besaran terhadap sistem pendidikan Barat. Namun langkah tersebut ternyata justru mendatangkan masalah baru. Masalah baru tersebut disebabkan beberapa faktor yaitu, a) adanya sikap tertutup dikalangan ilmuan muslim yang menolak mempelajari ilmu-ilmu "non-agama", b) adanya sikap memilih-milih antara "ilmu agama" dan "ilmu non agama", dan c) adanya sikap yang agnostic terhadap hal-hal yang berbau non Islam (Baharudin, 2011: 35).

Hal itu menjadikan penyempitan makna pendidikan Islam. Penyempitan tersebut akibat dari terpolarisasi makna pendidikan Islam yang sesungguhnya, pendidikan Islam identik dengan pendidikan (agama dan keagaaman) tanpa memberi tempat keilmuan-keilmuan yang lain. Sementara disisi yang lain terdapat pendidikan Islam yang mengadopsi Barat (ala Barat) yang pada perkembangannya mulai kehilangan ruh-ruh mendasarnya (trasendental). Munculnya dua model pendidikan mengakibatkan ambivalensi orientasi pendidikan Islam, yang salah satu dampak negatifnya adalah adanya paradigma dualism-dikotomis dalam sistem pendidikan Islam. 
Implikasi dari anggapan tersebut terhadap paradigma umat Islam, jelas menimbulkan konsekuensi yang tidak kecil. Pertama, adalah pendidikan Islam yang muncul menjadi suatu konstruksi wacana pada tataran filosofis, metodologis, dan wacana praksis sangat jauh dariaspek antroposentris-humanistik. Artinya kandungan nilai-nilai yang ada dalam pendidikan Islam menjadi nilai-nilai samawi yang hanya diperuntukkan untuk aspek "teosentris" an sich dan mereduksi nilai-nilai untuk kemanusiaan. Kedua, umat Islam berlomba-lomba untuk menjadi "orang salih"dengan mempelajari "ilmu agama" dan meninggalkan "ilmu umum". Akhirnya, image yang muncul dan pernah berkembang adalah stigma-stigma untuk umat Islam tidak lebih dari "kaum tradisional", terkesan kuno dan ortodoks. Alih-alih terlibat untuk menciptakan dan mengembangkan temuan-temuan ilmu pengetahuan dan tekhnologi yang baru, mengikuti dan menggunakannya saja pun belum mampu. Endingnya, umat Islam hanya bisa mengadopsi pendidikan sekuler modern sebagaimana telah berkembang secara umumnya di dunia Barat dan mencoba untuk "mengislamkannya".

Padahal pendidikan Islam tidak terbatas pada pendidikan agama atau khusus keagamaan dan juga bukan sekedar pendidikan yang diberi label Islam. Pendidikan Islam adalah segala usaha untuk memelihara fitrah manusia dan mengembangkan SDM menuju terbentuknya manusia seutuhnya (beriman dan betakwa) sehingga mampu mengemban perannya sebagai khalifatu fi al-ardl. Untuk menjadi khalifatullah tidak cukup hanya berbekal ilmu agama saja. mengintegrasikan nilainilai Islam ke dalam seluruh kegiatan pendidikan, namun baru berfungsi sebagai bagian kecil dari pendidikan Islam.

\section{Catatan Akhir}

Filsafat pendidikan Islam merupakan bagian terpenting dalam dimensi keilmuan yang mengkhususkan mengkaji bangunan keilmuan pendidikan Islam sampai ke akar-akarnya. Filsafat pendidikan Islam juga dituntut untuk membahas segala 
permasalahan yang ada di dalam pendidikan Islam. Sampai sekarang filsafat pendidikan Islam mempunyai problem besar yang belum terselesaikan. Diantara permasalahan yang masih ada di dalam pendidikan Islam diantaranya dapat dikelompokkan menjadi tiga tema besar yaitu, masalah visi pendidikan Islam, epistemologi pendidikan, dan dualisme keilmuan pendidikan.

Visi pendidikan Islam masih bersifat utopis, dalam artian bahwa visi yang ditawarkan pendidikan Islam sangat universal. Padahal jika ditelisik dalam struktur ilmu, pendidikan merupakan sub bagian dari Islam, jadi visi pendidikan Islam merupakan turunan dari visi Islam. Permasalahan visi pendidikan kemudian menyebabkan pengajaran pendidikan Islam hanya mengajarkan ilmu-ilmu yang dapat mengantarkan kepada kesalehan individual. Out put pendidikan kemudian tidak mampu bersaing dalam dimensi sosial. sudah seharusnya visi pendidikan Islam diarahkan pada ranah-ranah sosial, sehingga ilmu kependidikan Islam dapat diaplikasikan.

Permasalahan kedua terkait dengan epistemology pendidikan Islam. Epistemologi merupakan cabang dari filsafat ilmu yang mengakaji tentang cara-cara memperoleh pengetahuan. Epistemologi pendidikan Islam berupaya meligitimasi kebenaran pengetahuan melalui sumber-sumber yang berasal dari Islam. Namun pada kenyataannya pendidikan Islam tidak ada bedanya dengan pendidikan yang lainnya. Cara untuk memperoleh ilmu pengetahuan dalam pendidikan Islam masih mengacu pada Barat (pendidikan umum), yang tidak mempunyai sumber-sumber keilmuan dari kitab suci. Kiranya hal ini, dapat menyebabkan reduksi kebenaran hanya menurut Barat, Islam yang memiliki tradisi keilmuan yang luas akhirnya hanya berpedoman pada standar-standar kebenaran yang dibatasi rasional-empiris.

Ketiga, terkait dengan dualisme keilmuan dalam pendidikan Islam. Ketegangan antara keilmuan Barat dan Islam sudah sejak lama ada di dalam bangunan keilmuan di Negara-negara Muslim. Pendidikan Islam di Negara-negara Muslim secara sistemik mengikuti pola pendidikan umum, namun secara kelembagaan 
mengikuti sumber-sumber Islam, khususnya dalam materi pelajaran. Tidak hanya itu, ilmu-ilmu yang ada di dalam pendidikan Islam tidak sepenuhnya mencerminkan keislamannya, keikutsertaan ilmu-ilmu umum dalam pendidikan Islam menyebabkan ilmu-ilmu Islam dipinggirkan, dan dinomor duakan.

\section{Daftar Pustaka}

Al-Faruqi, Ismail Raji'. 2003. Islamisasi Pengetabuan. terj. Anas Wahyudin. Bandung: Pustaka.

Baharudin dkk. 2011. Dikotomi Pendidikan Islam, Historisitas dan Implikasinya pada Masyarakat Islam. Bandung: Remaja Rosdakarya.

Bakar, Usman Abu dan Surohim. 2005. Fungsi Ganda Lembaga Pendidikan Islam. Yogyakarta: Safira Insan Press.

Fazlurrahman. 1997. Islam. terj. Ahsin Muhammad. Bandung: Pustaka.

Gallagher, Kenneth T. 1994. Epistemologi Filsafat Pengetabuan. terj. Hardono Hadi. Yogyakarta: Kanisius.

Nasution, Harun. 1975. Pembaharuan Dalam Islam, Sejarah Pemikiran dan Gerakan. Jakarta: Bulan Bintang.

Qomar, Mujamil. 2005. Epistemologi Pendidikan Islam. Jakarta: Penerbit Erlangga.

Sardar, Ziauddin. 1998. Jihad Intelektual Merumuskan Parameterparameter Sains Islam. terj. AE. Priyono. Surabaya: Risalah Gusti.

Saridjo, Marwan. 1996. Bunga Rampa Pendidikan Agama Islam. Jakarta: Amissco.

Tibi, Bassam. 1994. Krisis Peradaban Islam Modern, Sebuah Kultur PraIndustri Dalam Era Ilmu Pengetahuan dan Tekbnologi. terj. Yudian W. Asmin. Yogyakarta: Tiara Wacana.

Tilaar, HAR. 2000. Paradigma Baru Pendidikan Nasional. Jakarta: Rhineka Cipta.

Usa, Muslih, (ed). 1991. Pendidikan Islam di Indonesia antara Cita dan Fakta. Yogyakarta: Tiara Wacana. 
Problem Filsafat Pendidikan... (Muhammad Hatim)

Wibowo, A. Setyo. 2002. Gaya Filsafat Nietæ̌sche. Yogyakarta: Bentang.

Zaini, Syahminan. 1989. Integrasi Ilmu dan Aplikasinya Menurut alQur'an. Jakarta: Kalam Mulia. 